\title{
Monitoring sun bears and Asiatic black bears with remotely sensed predictors to inform conservation management
}

\author{
Lorraine Scotson, Steven Ross and Todd W. Arnold
}

\begin{abstract}
Asiatic black bear Ursus thibetanus and sun bear Helarctos malayanus populations are declining throughout South-east Asia as a result of habitat loss and human disturbance. Knowledge of the distribution and status of each species is limited and largely anecdotal. Range maps are coarse, compiled by expert opinion, and presence or absence is unknown over large portions of South-east Asia. These two species co-occur in Lao People's Democratic Republic and may be faring better there than in neighbouring countries. During 2010-2013 we searched for bear sign along 99 transects within eight study sites throughout Lao. To explore countrywide relative abundance and habitat suitability, we modelled bear sign as a log-linear function of biological and anthropogenic predictors that were associated with habitat assemblages and human disturbance. Bears favored higher elevations and rugged terrain in areas less accessible to humans, and were most abundant in the north and east of Lao. Suitable habitats were rare in the southern lowland plains where bear abundance was relatively low. Our model predicted that Nam Et-Phou Louey National Protected Area had the largest areas of suitable bear habitat, followed by the Nakai-Nam Teun and Nam Ha National Protected Areas. Using transects to survey for bear sign, we created a replicable geographical information system based assessment tool for bears in Lao that can be used to identify conservation opportunities and monitor changes in bear distribution over time.
\end{abstract}

Keywords Asiatic black bear, Helarctos malayanus, Lao People's Democratic Republic, remote sensing, sign transects, species distribution model, sun bear, Ursus thibetanus

\section{Introduction}

T ao People's Democratic Republic may be a core conservation area for the Asiatic black bear Ursus thibetanus and sun bear Helarctos malayanus. Compared with

LORRAINE SCOTSON (Corresponding author) and TODD W. ARnOld Department of Fisheries, Wildlife and Conservation Biology, University of Minnesota, St Paul, Minnesota, USA. E-mail scotsonuk@gmail.com

STEven Ross Office for Conservation of the Environment, Diwan of Royal Court, Muscat, Sultanate of Oman

Received 15 January 2018. Revision requested 3 July 2018.

Accepted 12 September 2018. First published online 27 May 2019. neighbouring countries, Lao has low human density (29 people $/ \mathrm{km}^{2}$ ), large areas of intact tropical forest, and extensive protected areas (Robichaud et al., 2001; Johnson et al., 2016). However, bears in Lao are threatened by poaching and habitat loss. Hunting bears is prohibited nationally and throughout most of South-east Asia, but poor law enforcement capacity coupled with the high value of bear gall bladders, paws and cubs creates a high incentive for poaching (Nooren \& Claridge, 2001; Scotson \& Brocklehurst, 2013). Commercial trade of Asian bears is considered one of the biggest threats to wild populations, with trade occurring domestically and internationally with China, Thailand and Viet Nam (Foley et al., 2011; Garshelis \& Steinmetz, 2016; Scotson et al., 2017a). Asian bears are also threatened by high rates of deforestation (Sodhi et al., 2010; Miettinen et al., 2011). Habitat loss is estimated to have reduced Lao's bear population by c. $12 \%$ during 2000-2014 (Scotson et al., 2017b). Asiatic black bears and sun bears are categorized as Vulnerable on the IUCN Red List, with populations projected to decline globally by $>30 \%$ in the next $30+$ years (Garshelis \& Steinmetz, 2016; Scotson et al., 2017a).

Historically, Asiatic black and sun bears were recorded in all provinces of Lao (Erdbrink, 1953; Lekagul \& McNeely, 1977), but current IUCN range maps suggest bear range is limited to national protected areas and some provincial protected areas (Garshelis \& Steinmetz, 2016; Scotson et al., 2017a,b; Fig. 1). However, the IUCN range maps are based on expert opinion, and conservation efforts are hampered by lack of empirical data. Effective conservation of bears requires improved knowledge of bear distribution and relative abundance, and a replicable method of monitoring populations over time.

Monitoring programmes must be affordable and applicable over large areas, with sampling strategies that allow extrapolation to non-surveyed areas. Lao is dominated by rugged terrain, and access to bear habitat is largely limited to areas that can be reached on foot from rural villages. Our objective was to construct and implement a practical, lowcost survey method for bears and use species distribution modelling to predict spatial patterns of bear occurrence and habitat suitability in relation to ecological and anthropogenic factors throughout the country. Our findings can be used to inform conservation management of bears by identifying areas of suitable bear habitat and where populations are most abundant. 


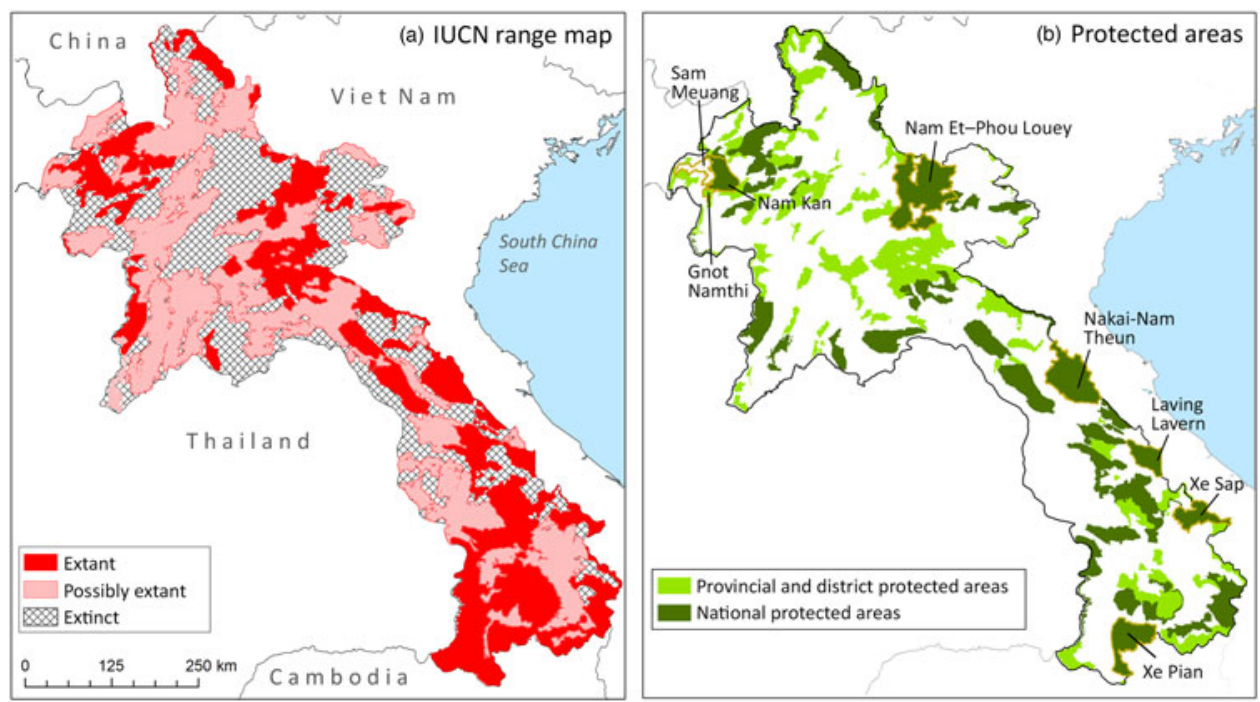

FIG. 1 (a) IUCN range map for the Asiatic black bear Ursus thibetanus and sun bear Helarctos malayanus in Lao PDR. Range is identical for the two species. Possibly extant range is likely to contain bears, based on habitat composition and proximity to definite range; extinct range is thought to be devoid of bears (IUCN, 2018). (b) National Protected Areas and Provincial and District Protected Areas in Lao PDR; the eight sites surveyed for bear sign during 2010-2013 are labelled (see Table 1 for details of each site), including one surveyed area outside protected areas (Sam Meuang Product Forest).

\section{Study area}

During 2010-2013 we surveyed eight study sites throughout Lao (Fig. 1); sites varied in elevation and proximity to villages (Table 1). Most sites were characterized by steep mountainous terrain with a diversity of forest types (including mixed evergreen and deciduous forest, dry evergreen and upper montane forest, and patchily distributed secondary forest), agricultural lands and anthropogenic grasslands, but Xe Pian National Protected Area in the southern lowland plains is a mosaic of semi-evergreen, mixed deciduous and dry dipterocarp forests and wetland habitat.

\section{Methods}

At each study site we searched for bear sign within 10-36 line transects that were $500 \mathrm{~m}$ long and 6 or $10 \mathrm{~m}$ wide. Transects were selected by generating a pool of random points within protected area boundaries using ArcGIS 9.3 (ESRI, Redlands, USA). Points were approached from the nearest village by walking directly towards each point and completing $500 \mathrm{~m}$ transects within different distance gradients from villages $(2-5,5-10,10-15$ and $15-20 \mathrm{~km})$. Transects were a minimum of $700 \mathrm{~m}$ apart. In Xe Pian National Protected Area, where habitat was flat and open, we walked long, continuous transects, and later systematically spaced each $500-\mathrm{m}$ segment by $1500-\mathrm{m}$ by removing segments of the transects.

We completed 99 transects totalling $61.34 \mathrm{~km}$ in length and covering 322.7 ha. Each transect was surveyed by a four- or five-person team, trained and led by LS (for detailed methods see Scotson, 2017). Sampling effort within forest types was approximately proportional to their areal coverage in Lao. We recorded all bear sign along transects, including claw marks on trees (representing c. $80 \%$ of all observed sign), bear nests, evidence of digging, broken rotten wood and broken bee nests (identified as bear sign by using pre-determined criteria and/or the presence of secondary bear sign; see Scotson, 2010 for descriptions and illustrations).We also recorded human sign (e.g. trail cutting, hunting, logging, camps), ungulate sign, bear food (ripe fruit, acorns), and forest composition. Bear signs were grouped into two age categories (Steinmetz \& Garshelis, 2010): $<_{1}$ year old (hereafter recent sign) and recent and old sign combined (hereafter all sign). If claw marks of different age categories were observed on a tree, we recorded only the most recent sign. Sign could rarely be identified to species, and therefore sign was attributed to both species. We assumed that the amount of recent bear sign was directly proportional to the number of bears using the site and therefore was a measure of relative abundance (Seber \& Schwarz, 1999). All sign was assumed to reflect general habitat suitability because older claw marks remain visible for $>2$ years and accumulate at variable rates (Steinmetz \& Garshelis, 2010).

We modelled bear sign as a log-linear function of ecological and anthropogenic predictors using a single a priori mixed model selected based on sample size and degrees of freedom (Fieberg et al., 2009; Giudice et al., 2012). Allowable degrees of freedom were calculated as $m / 15$, where $m$ is 99 transects (Harrell, 2015), and therefore 99/15 $=6.6$ model parameters allowed, which we rounded up to 7 (excluding intercepts). We assumed our data followed a negative binomial distribution because count data are typically overdispersed (Gardner et al., 1995), with high frequencies of excess zeros that can often be explained by model covariates (Warton, 2005). We used random effects to account for 
TABLE 1 Characteristics of the eight study sites (Fig. 1) surveyed for bear sign in Lao PDR during 2010-2013.

\begin{tabular}{llll}
\hline Site name & Area $\left(\mathrm{km}^{2}\right)$ & Elevation range $(\mathrm{m})$ & No. of villages \\
\hline Nam Et-Phou Louey National Protected Area & 5,959 & $400-2,257$ & 100 \\
Nam Kan National Protected Area & 1,230 & $500-1,500$ & 60 \\
Gnot Namthi Provincial Protected Area & 161 & $600-800$ & 12 \\
Sam Meuang Production Forest & 787 & $600-900$ & 45 \\
Laving Lavern National Protected Area & 900 & $400-1,000$ & 50 \\
Nakai-Nam Theun National Protected Area & 3,710 & $700-1,500$ & 50 \\
Xe Sap National Protected Area & 1,335 & $700-1,500$ & 14 \\
Xe Pian National Protected Area & 2,400 & $200-844$ & 60 \\
\hline
\end{tabular}

${ }^{1}$ Numbers are approximate and include villages located inside and around park boundaries.

potential non-independence among transects within the same protected area. We considered ecological and anthropogenic variables thought to affect bear presence, collected locally or else extracted from a Geographic Information System (GIS). To reflect the small area covered by transects (0.3-0.5 ha), predictors were measured within circular plots with a radius of $350 \mathrm{~m}$ ( $0.35 \mathrm{ha})$ to explore how bears responded to their immediate surroundings. In addition to an intercept, our models included a negative binomial dispersion parameter, a random site effect, and five fixed covariates (Table 2). We selected model variables for inclusion in the a priori model based on: (1) their biological importance, (2) data availability, (3) the probability that future updates will become available for predictors that change over time, (4) their variation within study sites, and (5) their independence from other predictors (i.e. Pearson's $|r|<0.7$; Giudice et al., 2012). Considering these criteria, we selected \% tree cover (an indicator of forest type; Hansen et al., 2013), elevation, terrain ruggedness, and distances to nearest village and road for inclusion in the model (Table 2 ). We regarded \% tree cover and elevation as ecological covariates, whereas we presumed that ruggedness and distance to village and road are measures of potential anthropogenic disturbance. Locally collected predictors (human disturbance, food abundance, ungulate sign) were not available outside study sites, and therefore we explored their effects separately using post-hoc models.

We modelled the relationship between the expected count $\left(E\left[Y_{i}\right]\right)$ of bear sign on each transect as:

$$
\begin{aligned}
& \log \left(\frac{E\left[Y_{i}\right]}{\text { area }}\right)=\beta_{0}+\beta_{1} \text { Tree_cover }+\beta_{2} \text { Elevation } \\
& \quad+\beta_{3} \text { Ruggedness }+\beta_{4} \text { Dist_road }+\beta_{5} \text { Dist_village }+\varepsilon_{a}
\end{aligned}
$$

We ran two identical models using recent sign and all sign as the response variables. We included log transect area (o.01 ha) as an offset, and centred covariates using $z$-scores. We evaluated models with the intraclass correlation coefficient (ICC), which is the ratio of the between-cluster variance $\left(\varepsilon^{2}\right)$ to the total variance and is the proportion of total variance in the response that is accounted for by clustering of observations. The intraclass correlation coefficient can also be interpreted as the level of correlation among observations within the same cluster, and so indicates whether inclusion of a random effect is informative (McCullough \& Nelder, 1989). Using our model response variables, which were in a GIS database, we created a predictive distribution map. Using the ArcGIS raster calculator, $\mathrm{E}\left[\mathrm{Y}_{\mathrm{i}}\right]$ was predicted for each $0.7 \times 0.7 \mathrm{~km}$ pixel across Lao using our regression model equations, variable values from the GIS database, and the response variable estimates from our results. We interpreted the map generated from the recent sign model as reflective of relative bear abundance (Steinmetz \& Garshelis, 2010, Fredriksson, 2012) and the map generated from the all sign model as reflective of bear habitat suitability (because all sign included in the latter accumulate over a longer time period). We calculated the relative abundance of bears and the area of bear habitat inside and outside the Lao protected area network, with habitat and relative abundance categorized by the predicted number of bear sign; $<_{1}=$ marginal, $1-4=$ good, and $5=$ optimal.

Models were evaluated using Spearman's rank correlation between real and predicted values. We also tested models predictive performance using leave-one-out crossvalidation procedures (Abdi \& Williams, 2010). To test model performance at predicting sign counts at new sites, we repeated the cross-validation process with individual study sites as the sample unit. Cross-validation performance was assessed using receiver operating characteristic curves and area under the curve (AUC) values. We analysed data in $R$ 3.3.1 (R Core Team, 2016) with package $\operatorname{glm} m A D M B$, generated profile confidence intervals with $R$ function confint, and produced GIS covariates and predictive maps in ArcGIS.

\section{Results}

We observed 165 recent bear signs on 43 transects and a total of 455 bear signs on 77 transects (Fig. 2). Bear sign increased with elevation, ruggedness, tree cover, and distance from roads, although some of these relationships were significant only in the all sign model (Table 3, Fig. 3). Sign was 
TABLE 2 Environmental predictors considered for log-linear models of bear sign recorded on line transects in eight study sites in Lao that were sampled during 2000-2013. Ungulate, Food and Human disturbance were collected on transects; all other predictors were obtained from remote sensing data.

\begin{tabular}{|c|c|c|c|c|}
\hline Predictor $^{1}$ & Description & $\begin{array}{l}\text { Variability } \\
\text { within } \\
\text { study sites }\end{array}$ & $\begin{array}{l}\text { Degrees of } \\
\text { freedom }^{2}\end{array}$ & $\begin{array}{l}\text { Include in } \\
\text { model }(\mathrm{Y} / \mathrm{N})\end{array}$ \\
\hline Study site & 7 study sites $^{3}$ & & 1 & $\mathrm{Y}$ (random effect) \\
\hline$\%$ tree cover & $0-100 \%$ canopy cover & High & 1 & $\mathrm{Y}$ \\
\hline Forest type & 3 categories $^{4}$ & Low & 2 & $\mathrm{~N}$ \\
\hline Human influence index & $1 \mathrm{~km}^{2}$ (Sanderson et al., 2005) & Low & 1 & $\mathrm{~N}$ \\
\hline Road density & Within $10-\mathrm{km}$ buffer & Low & 1 & $\mathrm{~N}$ \\
\hline Distance to trading post & Distance in $\mathrm{km}$ to nearest known wildlife trading hub & Low & 1 & $\mathrm{~N}$ \\
\hline Distance to road & Distance in $\mathrm{m}$ to nearest road from middle of transect & High & 1 & $\mathrm{Y}$ \\
\hline Latitude & Lao ranges from 13 to $22^{\circ} \mathrm{N}$ & Low & 1 & $\mathrm{~N}$ \\
\hline Distance to river & Distance in $\mathrm{m}$ to nearest river from middle of transect & High & 1 & $\mathrm{~N}$ \\
\hline Distance to village & Distance in $\mathrm{m}$ to nearest village from middle of transect & High & 1 & $\mathrm{Y}$ \\
\hline Human density & Within $20-\mathrm{km}$ radius & Low & 1 & $\mathrm{~N}$ \\
\hline Elevation & Mean elevation of transect & High & 1 & $\mathrm{Y}$ \\
\hline Terrain ruggedness & Steepness \& undulations of terrain & High & 1 & $\mathrm{Y}$ \\
\hline Temperature & ${ }^{\circ} \mathrm{C}$, annual mean \& range & Low & 1 & $\mathrm{~N}$ \\
\hline Precipitation & Annual mean \& range & Low & 1 & $\mathrm{~N}$ \\
\hline Ungulate & Muntjac, sambar \& wild pig sign & High & 1 & Y (local model) \\
\hline Food & Ripe edible fruit \& acorns & High & 1 & Y (local model) \\
\hline Human disturbance & Any human sign (e.g. cutting, logging, footprints, camps) & High & 1 & Y (local model) \\
\hline
\end{tabular}

${ }^{1} \%$ tree cover derived from tree loss data for 2000-2012 (Hansen et al., 2013). Elevation derived from ASTER 30 m digital elevation model (DEM). Terrain ruggedness derived from DEM as a measure of steepness and terrain undulations.

${ }^{2}$ Number of regression parameters (coefficients, excluding intercept) needed to model each predictor as a linear effect, without interactions (adapted from Giudice et al., 2012).

${ }^{3}$ Gnot Namthi Provincial Protected Area and Sam Meuang Product Forest are combined as they are contiguous, with similar ecological and human-based conditions.

${ }^{4}$ Forest cover extracted from Geographic Information System land cover layer created by the Forest Inventory and Planning Division of the Department of Forestry, Lao. Categories were reduced from eight to three, based on ecological similarity, and expected bear use: (1) primary forest (lower dry evergreen and lower mixed deciduous), (2) degraded and secondary forest (bamboo, un-stocked forest), and (3) dry deciduous forest.

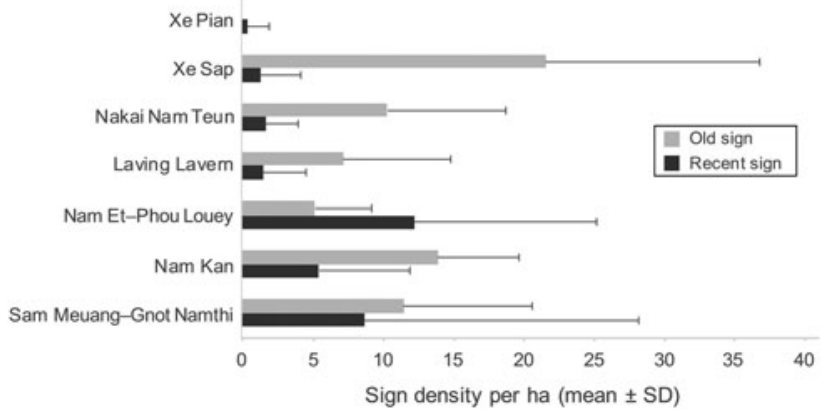

FIG. 2 Mean \pm SD density of old and recent bear sign per ha observed within line transects walked during 2010-2013 in eight sites in Lao (Fig. 1, Table 1). Sam Meuang Product Forest and Gnot Namthi Provincial Protected Area are combined, as they are contiguous.

negatively associated with human disturbance $(\mathrm{P}<0.001)$ and positively (but non-significantly) associated with ungulate sign and food abundance (Table 4 ).

For a-priori models $18 \%$ of stochastic variance in recent sign was explained by study site $(\mathrm{ICC}=0.18)$ vs $1.7 \%$ of variance in all sign $(\mathrm{ICC}=0.017)$. For post-hoc models, we observed the opposite pattern (all sign ICC $=0.27$; recent sign ICC $<0.01$ ). Low negative binomial dispersion parameters $(<2.5)$ indicated that negative binomial distributions were appropriate for all models.

Spearman's rank correlations between observed and predicted values were significant for both a priori models for recent sign $(r=0.337, \mathrm{P}<0.001)$ and for all sign $(r=0.535$, $\mathrm{P}<0.001)$. Receiver operating characteristic curves derived from leave-one-out cross validation had AUC values of 0.63 (95\% CI $0.46-0.77)$ for recent sign and 0.73 (95\% CI 0.53-0.89) for all sign.

Relative bear abundance based on recent sign was predicted to be highest in mountainous areas, particularly in the north and in the eastern mountainous areas that border Viet Nam. The all sign model predicted a wider area of bear habitat suitability than the recent sign model. Bear abundance was lowest in the southern tropical lowland plains, with only small patches of suitable habitat (Fig. 4). Fifty seven per cent of areas categorized as good bear habitat (predicted sign $=1-4 ; 67,314 \mathrm{~km}^{2}$ ) and $48 \%$ of optimal bear habitat (predicted sign $>5 ; 17,207 \mathrm{~km}^{2}$ ) fell outside the protected area network, equalling a total of $84,521 \mathrm{~km}^{2}$ 
TABLE 3 Model slopes $\left(\beta_{1}\right)$ and 95\% confidence intervals from two log-linear generalized mixed models, relating count of bear sign collected along straight line transects in Lao during 2010-2013 as a log-linear function of remotely sensed predictors ${ }^{1}$. The Recent sign model included sign $<1$ year old as the response, and the All sign model included sign of any age.

\begin{tabular}{|c|c|c|c|c|}
\hline \multirow[b]{2}{*}{ Predictors } & \multicolumn{2}{|c|}{ Recent sign model } & \multicolumn{2}{|c|}{ All sign model } \\
\hline & $\beta_{1}$ & $95 \% \mathrm{CI}$ & $\beta_{1}$ & $95 \% \mathrm{CI}^{2}$ \\
\hline Intercept & -3.94 & $-4.67--3.14$ & -2.34 & $-2.56--2.13$ \\
\hline Elevation (m) & 0.75 & $0.19-1.31$ & 0.64 & $0.37-0.92$ \\
\hline Distance to road (m) & 0.51 & $0.04-0.98$ & 0.32 & $0.11-0.54$ \\
\hline Tree cover $(\%)$ & 0.15 & $-0.51-0.80$ & 0.40 & $0.06-0.75$ \\
\hline Terrain ruggedness & 0.26 & $-0.42-0.43$ & 0.23 & $-0.03-0.48$ \\
\hline Distance to village (m) & 0.01 & $-0.42-0.43$ & -0.18 & $-0.40-0.05$ \\
\hline
\end{tabular}

${ }^{1}$ Predictors were centred using mean/SD. Models were offset by transect area $\left(\mathrm{m}^{2} / 100\right)$.

${ }^{2}$ Profile confidence intervals generated by $R$ function confint.
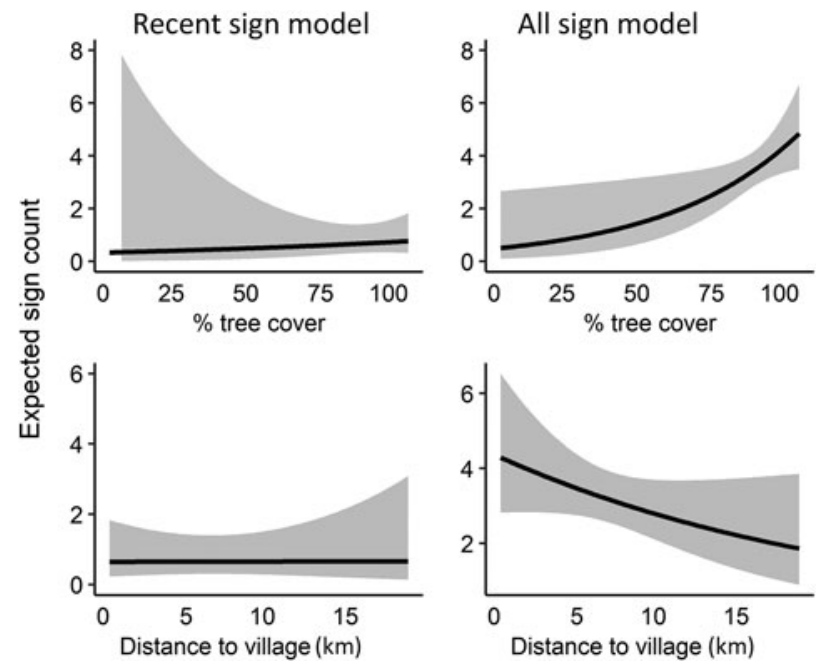

FIG. 3 Modelled relationships between expected count of bear sign on transects and distance to village and per cent tree cover. Bear sign were recorded within line transects in eight study sites in Lao (Fig. 1, Table 1) during 2010-2013. The left panels display relationships from a model of recent sign ( $<_{1}$ year old), and the right panels from a model of bear sign of all ages. Predicted values were generated using the predict function in $R$, with values for all other covariates fixed at their mean. The black line is the predicted response and the grey envelopes are the $95 \%$ confidence intervals.

(55\%) of suitable habitat (i.e. $>1$ predicted bear sign) situated outside the protected area network. Of all the protected areas in Lao, Nam Et-Phou Louey National Protected Area had the largest areas of suitable bear habitat (predicted sign $>1$; 4,000 $\mathrm{km}^{2}$ ) followed by Nakai-Nam Teun and Nam Ha National Protected Areas $\left(3,510 \mathrm{~km}^{2}\right.$ and $2,145 \mathrm{~km}^{2}$ respectively; Table 5).

\section{Discussion}

Modelling bear sign with biological and anthropogenic predictors gave us insight into bear distribution, relative abundance and habitat suitability in Lao. The maps identified key areas for conserving bears, including mountainous regions of the north, and along the eastern border with Viet Nam. Suitable bear habitat was also identified within large areas of forest outside protected areas, including some locations where bears are currently regarded as extirpated by IUCN. Bear presence was predicted to some degree in all 28 designated and proposed protected areas in Lao, with an area of suitable bear habitat (predicted sign $>1$ ) of $265-3157 \mathrm{~km}^{2}$ per protected area. According to our predictions, the area of suitable bear habitat exceeded $1,000 \mathrm{~km}^{2}$ for more than $50 \%$ of protected areas in Lao and, based on area alone, Nam Et-Phou Louey National Protected Area (northeastern), Nakai-Nam Theun National Protected Area (eastern) and the Nam Ha National Protected Area (northern) may be the most important protected areas for bear conservation (Table 5). By periodically updating remotely sensed predictors, our models can be used as a GIS-based monitoring tool to predict changes in bear distribution caused by changes in forest cover and human land-use over time.

Using sign to index relative abundance is a common, yet contentious monitoring method (Barnes, 2001; Stephens et al., 2015). Ngoprasert et al. (2015) found sign density to reflect differences in abundance between Asiatic black bears and sun bears, and Diefenbach et al. (1994) demonstrated a positive relationship between sign index of bobcats Felis rufus and abundance. Key assumptions for sign being proportional to abundance include a constant rate of sign deposition amongst individual bears and no heterogeneity in sign detection by survey teams (Seber \& Schwarz, 1999). Although violation of assumptions is inevitable to some degree in a large-scale uncontrolled study, we believe our predictions reflect the relative abundance of bears, and that our method is a significant improvement on expert opinion data currently available for Lao. Considering the financial and logistic constraints inherent in Lao, sign transects also provide an inexpensive and practical monitoring method for bear populations.

Poaching for commercial trade is considered the primary threat to bears in South-east Asia (Garshelis \& Steinmetz, 
TABLE 4 Model slopes $\left(\beta_{1}\right)$ and 95\% confidence intervals from two log-linear generalized mixed models, relating count of bear sign collected along straight line transects in Lao during 2010-2013 as a log-linear function of locally collected predictors ${ }^{1}$. The Recent sign model included sign $<1$ year old as the response, and the All sign model included sign of any age.

\begin{tabular}{lllll}
\hline & \multicolumn{2}{l}{ Recent sign model } & & \multicolumn{2}{c}{ All sign model } \\
\cline { 2 - 3 } \cline { 5 - 6 } Predictors & $\beta_{1}$ & $95 \% \mathrm{CI}$ & \multicolumn{1}{c}{$\beta_{1}$} & $-7.24--5.89$ \\
\hline Intercept & -8.90 & $-9.50--8.30$ & -6.57 & $-0.23--0.05$ \\
Human disturbance & -1.73 & $-2.69--0.76$ & -0.14 & $-0.04-0.07$ \\
Ungulate sign & 0.17 & $-0.25-0.58$ & 0.02 & $-0.05-0.08$ \\
Fruit abundance & 0.55 & $-0.07-1.17$ & 0.01 & \\
\hline
\end{tabular}

${ }^{1}$ Predictors were centred using mean/SD. Models were offset by transect area $\left(\mathrm{m}^{2} / 100\right)$.

${ }^{2}$ Profile confidence intervals generated by $R$ function confint.
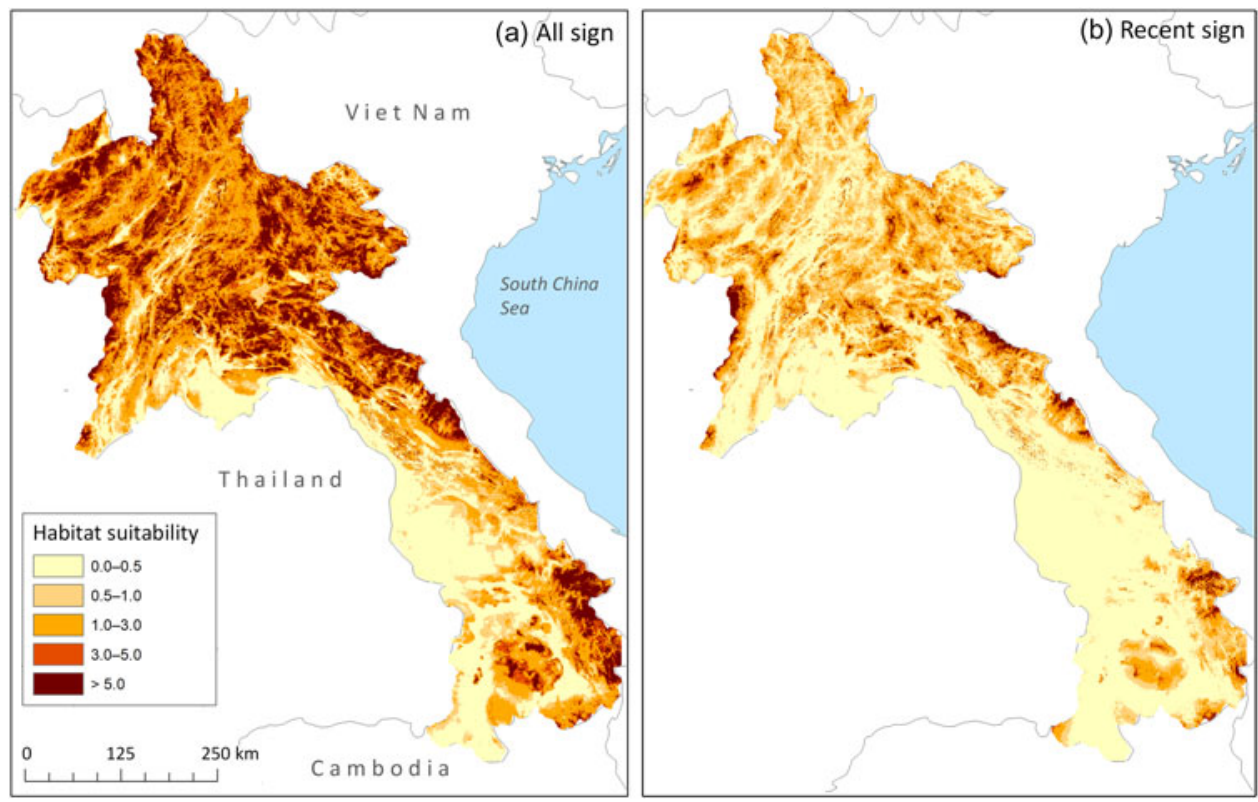

FIG. 4 Predicted distribution of Asiatic black bear and sun bear in Lao, based on sign collected on line transects in eight study sites (Fig. 1, Table 1) during 2010-2013. Predictions were generated from models in which log bear sign was a linear function of elevation, distance to road, terrain ruggedness, $\%$ tree cover and distance to village (Table 3 ). (a) Predictions made using sign of all ages (as sign accumulates over long periods this is considered to reflect habitat suitability),

(b) predictions made using recent sign $(<1$ year old; considered to reflect current distribution and relative abundance of bear populations).

2016; Scotson et al., 2017a,b). Wildlife poaching is widespread in Lao (Scotson \& Brocklehurst, 2013) and in some areas the decline of bear populations may be a result of overhunting rather than habitat loss. To account for this our models included predictors commonly associated with human accessibility and therefore potential poaching levels (Brodie et al., 2015). As expected, bears selected habitat less accessible by humans, in areas of high elevation, with high \% tree cover, at greater distance from roads, and in areas with lower signs of human activity.

Model-based predictions differed from the expert opinionbased range maps (IUCN, 2018; Fig. 1). We found evidence of bear occurrence in all study sites in Lao with extensive areas of suitable habitat, concentrated in mountainous regions of the north and east. Importantly, models predicted bear range in areas presently marked as extirpated by the IUCN, most notably in the northern highlands. Our results suggested that bear habitat suitability is very low in the southern lowland plains, contradicting areas marked as extant and possibly extant by IUCN (Garshelis \& Steinmetz, 2016; Scotson et al., 2017a,b; Fig. 4). Overall, our study represents a significant advance in knowledge of bear distribution patterns in Lao, with our results suggesting that the status of the national bear population is relatively better than in neighbouring range countries and that Lao is a core area for bear conservation in South-east Asia.

Our maps provide useful tools to help guide bear conservation in Lao. Firstly, activities to conserve core bear populations will be most effective if proactive measures such as population monitoring, snare removal, law enforcement patrols and community awareness activities are targeted in areas with the highest predicted bear abundance. Secondly, there is a need to evaluate bear presence and status in areas predicted as suitable habitat that fall outside currently documented bear range, and to protect these areas if bear presence is confirmed. Thirdly, patches of suitable habitat may be valuable for maintaining connectivity between core habitats, and could potentially be used to restore extirpated 
TABLE 5 Area of predicted bear habitat within individual National Protected areas in Lao, ranked from smallest to largest, using distribution models created from all bear sign encountered (all sign models).

\begin{tabular}{|c|c|c|c|}
\hline Protected area & $\begin{array}{l}\text { Suitable habitat } \\
\left(\mathrm{km}^{2}\right)^{1}\end{array}$ & $\begin{array}{l}\text { Optimal habitat } \\
\left(\mathrm{km}^{2}\right)^{2}\end{array}$ & $\begin{array}{l}\% \text { of suitable habitat } \\
\text { in protected area }\end{array}$ \\
\hline Phou Phanang & 269 & 2 & 39 \\
\hline Phou Xiengthong & 334 & 1 & 32 \\
\hline Xe Bang Nouan & 586 & 13 & 45 \\
\hline Phou Kathong & 591 & 55 & 55 \\
\hline Hin Nam No & 599 & 75 & 68 \\
\hline Corridor Nakai-Nam Theun \& Phou Hin Poun & 614 & 16 & 79 \\
\hline Phou Xang He & 633 & 4 & 55 \\
\hline Phou Kateup & 644 & 234 & 88 \\
\hline Nam Chuane & 711 & 520 & 73 \\
\hline Nam Xam & 718 & 294 & 94 \\
\hline Dong Phou Vieng & 760 & 61 & 37 \\
\hline Dong Houa Sao & 795 & 132 & 83 \\
\hline Phu Luang & 821 & 179 & 82 \\
\hline Laving Lavern & 866 & 100 & 66 \\
\hline Xe Khampho & 976 & 63 & 85 \\
\hline Phou Theung & 983 & 81 & 71 \\
\hline Xe Pian* & 1,196 & 3 & 46 \\
\hline Phou Khao Khoay & 1,341 & 128 & 74 \\
\hline Xe Sap ${ }^{*}$ & 1,397 & 931 & 91 \\
\hline Nam Kan* & 1,401 & 580 & 98 \\
\hline Phou Hin Poun & 1,410 & 159 & 59 \\
\hline Dong Ampham & 1,532 & 685 & 75 \\
\hline Phou Dene Din & 1,619 & 379 & 88 \\
\hline Nam Kading & 1,623 & 569 & 96 \\
\hline Nam Pouy & 1,677 & 398 & 94 \\
\hline Nam Ha & 2,145 & 1,046 & 97 \\
\hline Nakai-Nam Theun ${ }^{\star}$ & 3,510 & 1,432 & 86 \\
\hline Nam Et-Phou Louey ${ }^{\star}$ & 4,004 & 1,719 & 98 \\
\hline
\end{tabular}

${ }^{1}$ Predicted sign count per map pixel $>1$.

${ }^{2}$ Predicted sign count per map pixel $>5$.

${ }^{\star}$ Surveyed for bear sign during 2010-2013.

bear populations, by managing core connected areas for population growth (Scharf \& Fernández, 2018) or by repopulating areas where bears have been locally extirpated (Wolf \& Ripple, 2018). Reintroduction of orphaned bear cubs to areas of suitable habitat may be a solution for the ever increasing population of captive bears in bear rescue centres throughout South-east Asia (Garshelis \& Steinmetz, 2016; Scotson et al., 2017a). Fourthly, sign transects offer an effective and affordable solution to bear monitoring when resources are limited, and are compatible with ranger monitoring systems (e.g. SMART, 2013). Rangers can be trained in sign survey techniques, and enlisting ranger teams to conduct sign surveys would reduce operating costs by use of existing resources. Furthermore, expanded activities by ranger teams in protected areas would improve the visibility of law enforcement, serving to deter human incursion and illegal activities. Although mobilizing rangers in new ways would be helpful, it is not a panacea for protecting bears. Fundamental to conserving bears in Lao is the implementation of effective law enforcement to reduce poaching and trade, which are decimating wildlife populations throughout much of South-east Asia (Johnson et al., 2016). In most areas of Lao this requires additional long-term funding for the development of protected area infrastructure, to mobilize rangers, build capacity and provide necessary equipment.

Acknowledgements LS thanks all in the Government of Lao who facilitated this project and the field technicians who assisted in data collection. We thank the Wildlife Conservation Society and the faculty at the National University of Lao for technical support and field permits, Matt Hunt and Free the Bears, and Perth Zoo, The Hauser Bear Foundation, The International Bear Association's Research and Conservation Grant and Experience and Exchange Grant, Alertis Fund for Bear and Nature Conservation, The Margaret Dawbarn Foundation and Estate Robin Under Rothwell Account Wildlife Preservation Trust, managed by Perpetual, Colchester Zoo's Action for the Wild Fund, Kölner Zoo, and the University of Minnesota's Doctoral Dissertation Fellowship and Conservation Biology Summer Grant for funding.

Author contributions Study design: all authors; fundraising, field work writing: LS; GIS analysis: SR; contributed to analysis, writing and revision: SR, TA. 


\section{Conflicts of interest None.}

Ethical standards This research complied with the Oryx Code of Conduct.

\section{References}

Aвdi, H. \& Williams, L.J. (2010) Jackknife. In Encyclopedia of Research Design (ed. N.J. Salkind), pp. 655-66o. Sage, Thousand Oaks, USA.

BARNES, R.F.W. (2001) How reliable are dung counts for estimating elephant numbers? African Journal of Ecology, 39, 1-9.

Brodie, J.F., Giordano, A.J., Zipkin, E.F., Bernard, H., Mohd-Azlan, J. \& AMBU, L. (2015) Correlation and persistence of hunting and logging impacts on tropical rainforest mammals. Conservation Biology, 29, 110-121.

Diefenbach, D.R., Conroy, M.J., Warren, R.J., James, W.E., BAKER, L.A. \& Hon, T. (1994) A test of the scent-station survey technique for bobcats. The Journal of Wildlife Management, 58, $10-17$.

ERdBrink, D.P. (1953) A Review of the Fossil and Recent Bears of the Old World with Remarks on their Philogenese Based upon their Dentition. Drukkerij Jan de Lange, Deventer, The Netherlands.

FieberG, J., Rieger, R.H., Zicus, M.C. \& Schildcrout, J.S. (2009) Regression modelling of correlated data in ecology: subject-specific and population averaged response patterns. Journal of Applied Ecology, 46, 1018-1025.

Foley, K.E., Stengel, C.J. \& Shepherd, C.R. (2011) Pills, Powers, Vials and Flakes: the Bear Bile Trade in Asia. TRAFFIC Southeast Asia, Petaling Jaya, Malaysia.

Fredriksson, G. (2012) Effects of El Niño and large-scale forest fires on the ecology and conservation of Malayan sun bears (Helarctos malayanus) in East Kalimantan. $\mathrm{PhD}$ dissertation. University of Amsterdam, Amsterdam, The Netherlands.

Gardner, W., Mulvey, E.P. \& Shaw, E.C. (1995) Regression analyses of counts and rates: Poisson, overdispersed Poisson, and negative binomial models. Psychological Bulletin, 118, 392-404.

Garshelis, D. \& Steinmetz, R. (2016) Ursus thibetanus. In IUCN Red List of Threatened Species. Http://dx.doi.org/10.2305/IUCN.UK. 2016-3.RLTS.T22824A45034242.en [accessed 10 May 2017].

Giudice, J.H., FieberG, J.R. \& LenarZ, M.S. (2012) Spending degrees of freedom in a poor economy: a case study of building a sightability model for moose in northeastern minnesota. Journal of Wildlife Management, 76, 75-87.

Hansen, M.C., Potapov, P.V., Moore, R., Hancher, M., Turubanova, S.A., Tyukavina, A. et al. (2013) High-resolution global maps of 21st-century forest cover change. Science, 342, 850-853.

Ha Rrell, F. (2015) Regression Modeling Strategies: with Applications to Linear Models, Logistic and Ordinal Regression, and Survival Analysis. Springer, New York, USA.

IUCN (2018) The IUCN Red List of Threatened Species. Version 2018-1. Http://www.iucnredlist.org [accessed 7 October 2018].

Johnson, A., Goodrich, J., Hansel, T., Rasphone, A., Saypanya, S., Vongkhamheng, C., et al. (2016) To protect or neglect? Design, monitoring, and evaluation of a law enforcement strategy to recover small populations of wild tigers and their prey. Biological Conservation, 202, 99-109.

Lekagul, B. \& McNeely, J.A. (1977) Mammals of Thailand. Association for the Conservation of Wildlife, Bangkok, Thailand.
McCullough, P. \& Nelder, J.A. (1989) Generalized Linear Models. Chapman \& Hall, London, UK.

Miettinen, J., Shi, C. \& Liew, S.C. (2011) Deforestation rates in insular Southeast Asia between 2000 and 2010. Global Change Biology, 17, 2261-2270.

Ngoprasert, D., Gale, G., Vichitsoonthonkul, T. \& Vaeokhaw, S. (2015) Population Demographics and Genetics of Asiatic Black Bear and Sun Bear in the World Heritage Dong Phayayen-Khao Yai Forest Complex. Technical Report. King Mongkut's University of Technology Thonburi, Bangkok, Thailand.

Nooren, H. \& Claridge, G. (2001) Wildlife Trade in Laos: the End of the Game. IUCN, Amsterdam, The Netherlands.

R Core Team (2016) R: A Language and Environment for Statistical Computing. Http://www.r-project.org [accessed 1 April 2017].

Robichaud, W., Marsh, C.W.C., Southammakoth, S. \& Khounthikoummane, S. (2001) Review of the National Protected Area System of Lao PDR. Division of Forest Resource Conservation, Vientiane, Lao PDR.

Sanderson, J.G. \& Trolle, M. (2005) Monitoring elusive mammals. American Scientist, 93, 148-155.

Scharf, A.K. \& FernándeZ, N. (2018) Up-scaling local-habitat models for large-scale conservation: assessing suitable areas for the brown bear comeback in Europe. Diversity and Distributions, published online 9 July 2018.

Scotson, L. (2010) The distribution and status of Asiatic black bear Ursus thibetanus and Malayan sun bear Helarctos malayanus in Nam Et-Phou Louey National Protected Area, Lao PDR. Technical Report. Free the Bears, Luang Prahbang, Lao PDR.

Scotson, L. (2017) Distribution, range connectivity, and trends of bear populations in Southeast Asia. PhD thesis. University of Minnesota, St Paul, Minnesota, USA.

Scotson, L. \& Brocklehurst, M. (2013) Bear poaching in Lao PDR is exposed as an increasing threat to wild populations. International Bear News, 22, 22-23.

Scotson, L., Fredriksson, G., Augeri, D., Chea, C., Ngoprasert, D. \& WonG, W.M. (2017a) Helarctos malayanus Sun bear. In IUCN Red List of Threatened Species. Http://dx.doi.org/10.2305/IUCN.UK. 2017-3.RLTS.T9760A45033547.en [accessed 7 October 2018].

Scotson, L., Fredriksson, G., Ngoprasert, D., Wong, W.-M. \& FieberG, J. (2017b) Projecting range-wide sun bear population trends using tree cover and camera-trap bycatch data. PLOS ONE, 12, e0185336.

Seber, G.A.F. \& Schwarz, C.J. (1999) Estimating animal abundance: review III. Statistical Science, 14, 427-456.

SMART (2013) SMART Conservation Software. Http://www. smartconservationsoftware.org [accessed 10 October 2018].

Sodhi, N.S., Posa, M.R.C., Lee, T.M., Bickford, D., Koh, L.P. \& Brook, B.W. (2010) The state and conservation of Southeast Asian biodiversity. Biodiversity and Conservation, 19, 317-328.

SteinmetZ, R. \& Garshelis, D.L. (2010) Estimating ages of bear claw marks in Southeast Asian tropical forests as an aid to population monitoring. Ursus, 21, 143-153.

Stephens, P.A., Pettorelli, N., Barlow, J., Whittingham, M.J. \& Cadotte, M.W. (2015) Management by proxy? The use of indices in applied ecology. Journal of Applied Ecology, 52, 1-6.

WARTON, D.I. (2005) Many zeros does not mean zero inflation: comparing the goodness-of-fit of parametric models to multivariate abundance data. Environmetrics, 16, 275-289.

Wolf, C. \& Ripple, W.J. (2018) Rewilding the world's large carnivores. Royal Society Open Science, 5, 172235. 